\title{
Determinants of Household Demand for Insurance: The Case of Korea
}

\author{
Soon-Jae Lee ${ }^{\mathrm{a}}$, Soon Il Kwon ${ }^{\mathrm{b}}$ and Seok Young Chung ${ }^{\mathrm{c}}$ \\ ${ }^{a}$ School of Business, Sejong University, 98 Gunja-Dong, Gwangjin-Gu, Seoul 143-747, Republic of Korea. \\ ${ }^{\mathrm{b}}$ Korea Insurance Development Institute, 35-4 Yeido-Dong, Yeongdeungpo-Gu, Seoul 150-606, Korea. \\ ${ }^{\mathrm{c}}$ Faculty of Business \& Economics, Wonkwang University, 344-2 Shinyong-Dong, Iksan, Chullabuk-Do, \\ 570-749 Korea.
}

This article analyses the effect of household characteristics on the demand for insurance using consumer survey data in Korea. Using Tobit analysis, we have found that the selfemployed have a stronger demand for insurance than salaried workers, and that residents of small cities and rural areas purchase more protection-type insurance than metropolitan residents. Demand for insurance can differ depending on employment type and residential area, which has not been examined in previous studies. We have also found that there is a curvilinear relationship between age and demand for insurance. Results suggest that households with different demographic characteristics choose different risk-reducing instruments.

The Geneva Papers (2010) 35, S82-S91. doi:10.1057/gpp.2010.29;

published online 17 November 2010

Keywords: demand for insurance; household characteristics; employment type; residential area

\section{Introduction}

This article aims at estimating the demand for life insurance in Korea and pays particular attention to whether residential area and occupation type would influence the demand for insurance. It augments the empirical literature on insurance demand and follows a similar method to previous studies. However, there are some differences from previous studies that are worth noting.

First, this study examines the effect of household characteristics on demand not only for term life, but also for other protection-type and savings-type insurance. Savings-type insurance sold by private insurance companies is the combination of savings and insurance.

Second, previous studies did not pay much attention to the significance of residential area due to the lack of data. Using the cohort analysis, Chen et al. ${ }^{1}$ revealed that insurance demand from the baby boomer generation was quite different from that of previous generations. The cohort effect indicates that a group or an individual's experience or environmental exposure, such as residential area, can affect their

\footnotetext{
${ }^{1}$ Chen et al. (2001).
} 
demand for life insurance. Specifically, Showers and Shotick ${ }^{2}$ suggest that the different degree of risk individuals perceive based on different residential areas may lead to different demands for insurance. This study further examines the effect of residential area on insurance demand.

Third, in previous studies, employment type was not classified in detail. Rather, the major focus was on an individual's employment status, ${ }^{3}$ while the cohort effect and earning span actually indicates a closer relationship between employment type and insurance demand. According to previous theoretical studies (e.g., Campbell ${ }^{4}$ ), the major motive behind purchasing life insurance is explained by the uncertainty of future human capital and the possibility of the wage earner's non-survival. This means that differences in expected retirement ages should result in different demands on insurance, assuming similar income levels. Typically, self-employed individuals control their retirement age, and/or there is no specified retirement age. We expect that employment type should influence people's demand for life insurance.

In addition, many previous studies have used the amount insured as a dependent variable because of the lack of data. However, the amount of premium paid is a better way to measure demand for insurance and risk aversion, as premiums significantly vary among different insurance types or risks covered. For instance, premiums for disease coverage tend to be much higher than accident coverage, which has a lower frequency but higher severity. Therefore, the amount of premium paid is a better proxy to measure the demand for household insurance.

The rest of the article is composed as follows: The next section provides a brief discussion of the insurance market in Korea and explains variables and data for empirical analysis. Results of the analysis and discussion of the findings are described in the subsequent section.

\section{Institutional background and data}

\section{Insurance market in Korea}

Korea has been one of the fastest growing insurance markets in the world since the 1960 s, illustrated in its 2.4 per cent market share in 2005, ranking seventh in the world. ${ }^{5}$ Internally, the Korean insurance industry has shown high market concentration. Specifically, the top three life insurance companies accounted for 65.9 per cent of total premiums in 2005, while the top four non-life insurance companies occupied 71.3 per cent.

\footnotetext{
${ }^{2}$ Showers and Shotick (1994).

${ }^{3}$ Some studies (e.g., Hammond et al., 1967 and Mantis and Farmer, 1968) used "employment" as a variable for the wage earner's employment status, while other studies (e.g., Goldsmith, 1983 and Gandolfi and Miners, 1996) used as a variable for wife's employment status. This is the first study to classify the employment type into self-employed and other types. Other types of employment are mostly salaried workers.

${ }^{4}$ Campbell (1980).

${ }^{5}$ Swiss Re (2006).
} 
Table 1 Sales volume of each distribution channel in the Korean life insurance market: 2000 vs. 2005 (Unit: KRW 100 million)

\begin{tabular}{ccccccr}
\hline Year & \multicolumn{5}{c}{ First time premium by distribution channel (\%) } \\
\cline { 2 - 7 } & Solicitors & Agents & Sales staff & Bancassurance $^{\mathrm{b}}$ & Others $^{\mathrm{c}}$ & Total $^{\circ}$ \\
\hline 2000 & 155,830 & 5,445 & 26,391 & & 72 & 187,738 \\
& $(83.0)$ & $(2.9)$ & $(14.1)$ & & $(0.0)$ & 92,889 \\
2005 & 45,123 & 6,267 & 16,157 & 25,340 & 1 & $(0.0)$ \\
& $(48.6)$ & $(6.7)$ & $(17.4)$ & $(27.3)$ & & \\
\hline
\end{tabular}

${ }^{a} \mathrm{KRW}$ is the Korean currency unit. US\$1 = KRW1013.00 in 2005.

${ }^{\mathrm{b}}$ Bancassurance, began in 2003, includes insurance sales by banks and other finance firms.

${ }^{\mathrm{c}}$ Others include sales by mutual societies, post office, telemarketing, Internet and home shopping.

Corporate pension was introduced in December 2005, opening up new opportunities for the life insurance industry to expand its business. Also, competition among distribution channels intensified due to the implementation of cross-selling and expansion of bancassurance scope since 2006. In particular, bancassurance, selling insurance policies by banks through their branch networks, has significantly influenced the life insurance market ever since its introduction. As shown in Table 1, bancassurance sales in 2005 captured 27.3 per cent of total new life insurance business within the first two years of its introduction. According to the bancassurance implementation schedule, banks have been approved to sell savings-type and credit life insurance since August 2003, refund-type "third area"6 insurance since April 2005, and all other insurance since April 2008. ${ }^{7}$

Personal insurance products sold by life and non-life insurance companies are very similar. Long-term insurance sold by non-life insurers is the product combining protection and savings features. Also, accident, disease and pension insurance products have been sold by both industry sectors. Insurance products are available for consumers through various channels, including: solicitors, agents, sales staff, Internet, telemarketing, mutual society, post offices, banks and securities firms, and home shopping.

Of these channels, solicitors, who exclusively work for specific insurance companies, sold more than 80 per cent of life insurance, whereas non-life solicitors and agents accounted for 35 and 47 per cent, respectively, in 2005. The solicitor system arose as a major insurance distribution channel since the 1960s when the life insurance market began to expand in Korea. As college-educated male solicitors (called financial planners) of foreign insurance firms succeeded in selling life insurance products, most domestic insurance firms started recruiting college graduates to establish sales branches consisting of male solicitors only.

\footnotetext{
${ }^{6}$ The third area insurance includes sickness, personal accident and long-term care insurance products.

${ }^{7}$ Later, this schedule was postponed without time limit.
} 
Regardless, the sales volume of the traditional female solicitor channel still accounts for the greater majority of domestic insurers. Solicitors are superior to other channels in their capability to service consumers, as their sales strategy focuses on personal relationships such as kinship, regionalism and alumni networks. According to the "2005 Insurance Demand Survey", of all insurance products, the solicitor channel was the most favoured way of purchasing any life insurance, with "intimacy" selected as one of the main reasons next to "convenience". This result supports the significance of relationship marketing utilised by solicitors in Korea, despite the shifting trend with the growth of bancassurance.

Insurance agents are classified into exclusive (or tied) agents and independent agents. In Korea, exclusive agents have been dominant over independent agents in terms of number and sales volume, partly due to the late introduction of the latter in the 1990s compared to the former in 1980s in Korea. Banks, as insurance agents, have been rapidly expanding their presence in the life insurance market since the introduction of bancassurance in Korea in August of 2003.

\section{Data}

The data used in this analysis was obtained from consumer survey data collected by the Korea Insurance Development Institute (KIDI) ${ }^{8}$ in 2005. In order to focus on the impact of job type, 1,136 households with employed heads were selected from 1,200 observations. The sample consists of households that reported either some or no insurance expenditure. The data is representative of the population balanced by geographic region and age.

Table 2 summarises the survey variables relevant to the analysis. As apparent in the table, the square root of premium for protection-type (PROTECT) and savings-type insurance 9 (SAVINGS) are the two dependent variables in the analysis. The sum of PROTECT and SAVINGS, TOTAL, was added as a dependent variable to measure the demand for total insurance.

Independent variables include the age of household head (AGE), squared term of age of household head (AGESQ) and the household income (INCOME). Other binary independent variables include: household head with bachelor's degree (EDUC), selfemployed household head (EMP) and residents of large cities (RESI). As education can affect income, we added an interaction term, education $\times$ income (INTER).

The summary statistics for variables are also provided in Table 2. As the table indicates, the typical age of the head of household is 42.6 years old, and 44 per cent of the household heads have a bachelor's degree. On average, the amount of premium for protection-type insurance per household is 4 per cent of the household income, and the amount of premium for all risk-reducing instruments is 11 per cent of the household income. ${ }^{10}$

\footnotetext{
${ }^{8}$ Korea Insurance Development Institute (KIDI) (2005).

${ }^{9}$ Protection-type insurance includes accident insurance, disease insurance, critical illness (CI) insurance as well as term life insurance sold by either life or non-life insurers. Savings-type insurance means cash value policies such as whole life and variable life insurance sold by life insurers. Long-term insurance, sold by non-life insurers, is also included because of its savings feature.

${ }^{10} 113.08 / 2793.57=4 \% ; 304.23 / 2793.57=11 \%$.
} 
Table 2 Descriptive statistic for demographic and dependent variables

\begin{tabular}{|c|c|c|c|c|}
\hline Variables & Variable & Description & Mean & $\begin{array}{l}\text { Standard } \\
\text { deviation }\end{array}$ \\
\hline \multirow[t]{3}{*}{ Dependent } & PROTECT & $\begin{array}{l}\text { Premium for protection-type paid } \\
\text { by households (monthly) }\end{array}$ & 113.08 & 117.75 \\
\hline & SAVINGS & $\begin{array}{l}\text { Premium for savings-type paid by } \\
\text { households (monthly) }\end{array}$ & 152.49 & 214.26 \\
\hline & TOTAL & $\begin{array}{l}\text { Sum of PROTECT and SAVINGS } \\
\text { (monthly) }\end{array}$ & 262.20 & 259.02 \\
\hline \multirow[t]{5}{*}{ Independent } & AGE & Age of head of household & 42.63 & 9.55 \\
\hline & INCOME & Monthly income & $2,793.57$ & $1,225.45$ \\
\hline & RESI & $\begin{array}{l}\text { Binary variable equals one for } \\
\text { those who live in large cities }\end{array}$ & 0.48 & 0.50 \\
\hline & EMP & $\begin{array}{l}\text { Binary variable equals one if head } \\
\text { of household is self-employed }\end{array}$ & 0.43 & 0.50 \\
\hline & EDUC & $\begin{array}{l}\text { Binary variable equals one if head } \\
\text { of household has bachelor's degree }\end{array}$ & 0.44 & 0.50 \\
\hline
\end{tabular}

Note: Units for dependent variables and income are thousand Korean won (KRW).

The dependent variable in this analysis is truncated at zero, that is, the dependent variables are not continuous but limited to zero for a portion of the sample. Tobin ${ }^{11}$ and many others have indicated that ordinary least squares estimates tend to underestimate the influence of independent variables on the dependent variable when the dependent variable is truncated. Hence, the Tobit analysis is used to more accurately analyse the impact of household characteristics on demand for insurance. ${ }^{12}$

Tobit results can be disaggregated into two parts: (1) the change of those above the limit, weighted by the probability of being above the limit and (2) the change in the probability of being above the limit, weighted by the expected value of dependent variable if above. ${ }^{13}$ For example, 77 per cent of the observations in the first equation of Table 3 had non-limit responses for protection-type insurance. Therefore, we can say that 55.3 per cent of the total change in protection-type insurance demand due to a change in the independent variables can be attributed to marginal changes in the amount owned, while 44.7 per cent of the change is due to a change in the probability of owning insurance at all.

\section{Results and discussions}

Models using the square root of the dependent variables provided the best fit. The results of the Tobit models are shown in Table 3 . The parameter estimates in Table 3 represent the change in the desired square root of insurance premium.

\footnotetext{
11 Tobin (1958).

${ }^{12}$ Lifereg procedure in the SAS computational software system was used.

${ }^{13}$ MacDonald and Moffitt (1980).
} 
Table 3 Tobit regression results for household demand for different insurance products

\begin{tabular}{|c|c|c|c|}
\hline \multirow[t]{2}{*}{ Independent variables } & \multicolumn{3}{|c|}{ Dependent variables } \\
\hline & PROTECT & $S A V I N G S$ & TOTAL \\
\hline INTERCEPT & $\begin{array}{c}-26.5759 * * \\
(0.0000)\end{array}$ & $\begin{array}{c}-39.5172 * * \\
(0.0000)\end{array}$ & $\begin{array}{c}-29.5037 * * \\
(0.0000)\end{array}$ \\
\hline RESI & $\begin{array}{r}-0.8236^{*} \\
(0.0658)\end{array}$ & $\begin{array}{c}-1.1973 \\
(0.1063)\end{array}$ & $\begin{array}{c}-0.6034 \\
(0.2433)\end{array}$ \\
\hline AGE & $\begin{array}{l}1.4244 * * \\
(0.0000)\end{array}$ & $\begin{array}{l}1.6791 * * \\
(0.0000)\end{array}$ & $\begin{array}{l}1.6538 * * \\
(0.0000)\end{array}$ \\
\hline EDUC & $\begin{array}{c}1.5125 \\
(0.2073)\end{array}$ & $\begin{array}{l}4.9025^{* *} \\
(0.0140)\end{array}$ & $\begin{array}{l}2.7478 * * \\
(0.0468)\end{array}$ \\
\hline INCOME & $\begin{array}{l}0.0012 * * \\
(0.0000)\end{array}$ & $\begin{array}{l}0.0034^{* *} \\
(0.0000)\end{array}$ & $\begin{array}{l}0.0024^{* *} \\
(0.0000)\end{array}$ \\
\hline EMP & $\begin{array}{c}0.5736 \\
(0.2105)\end{array}$ & $\begin{array}{c}1.1423 \\
(0.1308)\end{array}$ & $\begin{array}{l}1.1230^{* *} \\
(0.0339)\end{array}$ \\
\hline INTER & $\begin{array}{c}-0.00005 \\
(0.2131)\end{array}$ & $\begin{array}{c}-0.0012^{*} \\
(0.0643)\end{array}$ & $\begin{array}{c}-0.0007^{*} \\
(0.0898)\end{array}$ \\
\hline AGESQ & $\begin{array}{c}-0.0154 * * \\
(0.0000)\end{array}$ & $\begin{array}{c}-0.0188^{* *} \\
(0.0000)\end{array}$ & $\begin{array}{c}-0.0182^{* *} \\
(0.0000)\end{array}$ \\
\hline Number of observations ${ }^{a}$ & 875 & 716 & 992 \\
\hline Fraction of sample with insurance & 0.770 & 0.631 & 0.873 \\
\hline Estimated probabilities & 0.553 & 0.442 & 0.672 \\
\hline Log likelihood ratio ( $p$-value) & $\begin{array}{r}119.21^{* *} \\
(0.0000)\end{array}$ & $\begin{array}{r}156.66^{* *} \\
(0.0000)\end{array}$ & $\begin{array}{r}206.00 * * \\
(0.0000)\end{array}$ \\
\hline
\end{tabular}

aAmong 1136 households selected for analysis, 875 owned protection-type insurance, 716 owned savingstype insurance, and 992 owned either protection- or savings-type insurance.

Note: Two-tailed $p$-values are given in brackets $(* * p<0.05, * p<0.1)$.

The null hypothesis of "log likelihood ratio test" is "all independent variables are zero".

\section{Protection-type insurance}

As expected, age of household head (AGE) and household income (INCOME) are positively related to the demand for protection-type insurance (PROTECT) at a 1 per cent level of significance. In all previous studies, income was found to be positively related to demand for insurance as shown in Table 4. The positive relationship of age with the insurance demand is consistent with the findings of Truett and Truett ${ }^{14}$ and Showers and Shotick. ${ }^{2}$

The combined effect of the two "AGE" terms means that insurance ownership increases until age 47 and decreases afterwards, which is in line with insuring the potential loss of future labour income. When the wage earner grows older and approaches retirement, his (or her) human capital uncertainty diminishes and the cumulative probability of living decreases. This decreases the demand for the household head's own insurance. Owing to this feature, there is a curvilinear relationship between age and demand for insurance, as Showers and Shotick ${ }^{2}$ previously found. With a better understanding of the necessity to protect dependents from a wage earner's premature

\footnotetext{
14 Truett and Truett (1990).
} 
Table 4 Summary of previous studies on demand for insurance

\begin{tabular}{|c|c|c|}
\hline Author (s) & Explanatory variables & Results \\
\hline $\begin{array}{l}\text { Hammond } \\
\text { et al. }{ }^{15}\end{array}$ & $\begin{array}{l}\text { - Income, net assets, education, } \\
\text { marriage, children, occupation, race }\end{array}$ & $\begin{array}{l}\text { - Income, net assets, education and } \\
\text { occupation are positive } \\
\text { - No marriage and no children are negative }\end{array}$ \\
\hline $\begin{array}{l}\text { Mantis and } \\
\text { Farmer (1968) }\end{array}$ & $\begin{array}{l}\text { Relative price (of life insurance), } \\
\text { marriages, births, personal income, } \\
\text { population size, employment }\end{array}$ & $\begin{array}{l}\text { - Relative price, income and population are } \\
\text { positive } \\
\text { - Marriages, births and employment are } \\
\text { negative }\end{array}$ \\
\hline Goldsmith (1983) & $\begin{array}{l}\text { - Education of housewife, } \\
\text { employment of housewife, family } \\
\text { size, assets, current income, } \\
\text { ownership of other insurance }\end{array}$ & $\begin{array}{l}\text { - Education and income are positive } \\
\text { - Employment, family size, assets and other } \\
\text { insurance are negative }\end{array}$ \\
\hline $\begin{array}{l}\text { Burnett and } \\
\text { Palmer }^{16}\end{array}$ & $\begin{array}{l}\text { - Age, gender, marriage, number of } \\
\text { children, occupation, education, } \\
\text { race, religion, income }\end{array}$ & $\begin{array}{l}\text { - Number of children, education and income } \\
\text { are positive }\end{array}$ \\
\hline $\begin{array}{l}\text { Truett and } \\
\text { Truett }^{14}\end{array}$ & $\begin{array}{l}\text { - Age, education, income } \\
\text { - Comparison of income elasticity } \\
\text { between Mexico and the U.S. }\end{array}$ & $\begin{array}{l}\text { - All three variables are positive } \\
\text { - Income elasticity of demand for life } \\
\text { insurance is higher in Mexico }\end{array}$ \\
\hline $\begin{array}{l}\text { Showers and } \\
\text { Shotick }^{2}\end{array}$ & $\begin{array}{l}\text { - Household income, age of } \\
\text { household head, family size, } \\
\text { number of earners in the household }\end{array}$ & - All four variables are positive \\
\hline $\begin{array}{l}\text { Gandolfi and } \\
\text { Miners }^{17}\end{array}$ & $\begin{array}{l}\text { - Income, age, education, family size, } \\
\text { duration of child support, home } \\
\text { ownership, wife's employment } \\
\text { status } \\
\text { - Gender difference between husband } \\
\text { and wife }\end{array}$ & $\begin{array}{l}\text { - Income is positive for both } \\
\text { - Education, spouse education, home } \\
\text { ownership, wife's full-time employment } \\
\text { are significant for husband } \\
\text { - Education, home ownership, wife's } \\
\text { full-time/part-time employment, duration } \\
\text { of child support are significant for wife }\end{array}$ \\
\hline
\end{tabular}

death and their awareness of various types of insurance products, the educated may have a stronger desire to protect the dependents in this way. This explanation suggests that the level of education would be positively related to demand for insurance. However, our results show positive but insignificant relation to the demand for protection-type insurance, contradicting the findings of previous studies (e.g., Hammond et al., ${ }^{15}$ Burnett and Palmer, ${ }^{16}$ Truett and Truett, ${ }^{14}$ Gandolfi and Miners ${ }^{17}$ ).

Residential area (RESI) is also significantly related to the demand for protectiontype insurance (PROTECT) at a 10 per cent level. The negative sign of RESI illustrates

\footnotetext{
15 Hammond et al. (1967).

${ }^{16}$ Burnett and Palmer (1984).

${ }^{17}$ Gandolfi and Miners (1996).
} 
that those who live in small cities or rural areas are more likely to purchase protectiontype insurance than those in large cities, which is likely the result of the availability of employee benefit plans and solicitors' sales strategies. Specifically, those in large cities are more likely to receive employer-sponsored insurance, typically term life and health insurance, due to a higher chance of employment. Residents of rural areas are more likely to live upon relationships such as kinship and regionalism, which leads to easy marketing by solicitors.

\section{Savings-type insurance}

Education (EDUC) and household income (INCOME) are significantly and positively related to the demand for savings-type insurance (SAVINGS). Education (EDUC) is not significant in the PROTECT equation, which is contradictory to the results of previous studies. However, education (EDUC) is significant in the SAVINGS equation, which means that education makes no difference in the demand for protection-type insurance but makes some difference in the demand for complex riskreducing instruments such as variable life and whole life insurance, coinciding with our expectation. The differences in significance among the models prove that all risk-reducing instruments should be considered when examining the demand for life insurance and testing for risk aversion.

Age (AGE) and age squared (AGESQ) are strongly significant at a 1 per cent level and their signs are positive and negative, respectively, as we expected. The negative coefficient of the interaction term (INTER) indicates that given the positive effect of income, well-educated household heads tend to buy less savings-type insurance. That is, people with higher education tend to buy less insurance, given the same income level. This can be explained by the tendency of education to encourage people to find alternative ways to reduce the risk of household income variation, given that insurance is purchased to reduce the risk of income variation. In other words, at a given level of income, education is the substitute good for insurance.

\section{Total personal insurance}

Employment type (EMP) is very significant in the TOTAL equation and the sign of the coefficient is also positive, showing that the demand for insurance increases if the head of the household is self-employed. This result indicates the difference in insurance demand according to the employment type.

In the TOTAL equation, age of household head (AGE), job type (JOB) and household income (INCOME) are strongly significant and positively related as initially expected. The interaction term (INTER) and age squared (AGESQ) are also significant.

This article empirically examined the effects of demographic factors on household demand for insurance. The primary contribution of this study is that employment type and residential area were found to be additional demographic variables that influence people's demand for insurance. Self-employed workers were found to have stronger demand for insurance than salaried workers. People who live in small cities or rural areas have a stronger demand for insurance than those in large cities. 
S90

Another contribution of this study is that households with different demographic characteristics were found to choose alternative risk-reducing instruments. For example, people who live in small cities or rural areas are more likely to purchase protection-type insurance than those in large cities, because of their low availability of employer-sponsored insurance plans and concerns over protecting their dependents.

These results signal opportunities for insurance companies to approach consumers with different marketing strategies, depending on their residential areas and employment types as well as other demographic characteristics. It is suggested that insurance companies promote protection-type insurance products for the consumers in small cities and rural areas, while more marketing efforts be made for self-employed workers.

\section{Acknowledgement}

The authors appreciate the Korea Insurance Development Institute (KIDI) for allowing use of its "2005 Insurance Demand Survey" data.

\section{References}

Burnett, J.J. and Palmer, B.A. (1984) 'Examining life insurance ownership through demographic and psychographic characteristics', The Journal of Risk and Insurance 51(3): 453-467.

Campbell, R.A. (1980) 'The Demand for life insurance: An application of the economics of uncertainty', The Journal of Finance 35(5): 1155-1172.

Chen, R., Wong, K.A. and Lee, H.C. (2001) 'Age, period, and cohort effects on life insurance purchases in the U.S', The Journal of Risk and Insurance 68(2): 303-327.

Gandolfi, A.S. and Miners, L. (1996) 'Gender-based differences in life insurance ownership', The Journal of Risk and Insurance 63(4): 683-693.

Goldsmith, A. (1983) 'Household life cycle protection: Human capital versus life insurance', The Journal of Risk and Insurance 50(3): 473-486.

Hammond, J.D., Houston, D.B. and Melander, E.R. (1967) 'Determinants of household life insurance premium expenditures: An empirical investigation', The Journal of Risk and Insurance 34(3): 397-408.

Korea Insurance Development Institute (2005) 2005 Insurance Demand Survey, Korea Insurance Development Institute, Seoul, Korea.

Korea Insurance Development Institute (2006) Korean Insurance Market 2006, Insurance Research Center, Seoul, Korea.

MacDonald, J.F. and Moffitt, R.A. (1980) 'The uses of Tobit analysis', The Review of Economics and Statistics 62(2): 318-321.

Mantis, G. and Farmer, R.N. (1968) 'Demand for life insurance', The Journal of Risk and Insurance 35(2): 247-256.

Showers, V.E. and Shotick, J.A. (1994) 'The effects of household characteristics on demand for insurance: A Tobit analysis', The Journal of Risk and Insurance 61(3): 492-502.

Swiss Re (2006) Sigma No. 5.

Tobin, J. (1958) 'Estimation of relationships for limited dependent variables', Econometrica 26(1): 24-36.

Truett, D.B. and Truett, L.J. (1990) 'The demand for life insurance in Mexico and the United States: A comparative study', The Journal of Risk and Insurance 57(2): 321-328.

\section{About the Authors}

Soon-Jae Lee received his $\mathrm{PhD}$ in Business Administration from Ohio State University in 1992, and taught management, finance, and risk management at Gardner-Webb University until 1995. After working in the insurance industry as Director of 
Corporate Planning Team at Samsung Fire \& Marine Insurance Company and Executive Director of Insurance Research Centre at Korea Insurance Development Institute (KIDI) for six years, he returned to Sejong Univeristy to resume teaching and research in insurance and risk management in 2001. He has explored various research areas ranging from insurance industry regulation, risk management in Records Management, to contingent valuation and Warm Glow. He is currently President of the Korea Insurance Academic Society.

Soon Il Kwon received his $\mathrm{PhD}$ in Economics from SungKyunKwan University in 2008. He has been working for the KIDI since 1995. He completed his MBA from University of Pittsburgh in 2006. He has conducted research on various areas such as insurance industry regulation, bancassurance and insurance market trend analysis. $\mathrm{He}$ is currently Senior Manager at KIDI.

Seok Young Chung received his $\mathrm{PhD}$ in Business Administration from the Univeristy of Texas at Arlington in 1998, and worked at the Hyndai Economic Research Center and KIDI as a researcher in the area of business strategy and risk management. He is currently Professor at Wonkwang University in Korea, and his research areas are international financial management, international business, derivative markets, and risk management. He is also serving as president of Local Government Research Center and the Editor of the Journal of Insurance Studies. 